\title{
PUBLIC-PRIVATE PARTNERSHIP PPP AS A FORM OF DELIVERING PUBLIC SERVICES
}

\author{
BEATA ZAGOŻDŻON
}

Kazimierz Pulaski University of Technology and Humanities in Radom, POLAND e+mailı b.zagozdzon@uthrad.pl

\author{
\begin{tabular}{l|l} 
RECEIVED & 10 July 2017
\end{tabular} \\ ACCEPTED $\quad 15$ December 2017 \\ JEL \\ CLASSIFICATION \\ KEYWORDS public services, PPP in Poland, critical success factors
}

ABSTRACT Determining the place and the role of the private sector in delivering public services is one of the problems that modern economics faces. It is currently believed that there are no goods and services that can only be provided by the private or the public sector. Governments use the form of public-private partnership PPP, which aims to create the components of infrastructure that enables the implementation of public services.

In Poland, the first concession contract with a private investor for the construction and operation of transport infrastructure was signed in 1997. The 20 years of experience with PPP projects leads to assessments and summaries.

The article presents a literature review, which shows that a high number of publications are devoted to the PPP, including identifying the factors for the success of PPP projects. Then, it focuses on the results of the analysis of these factors in terms of practical implementation of projects in Poland. Also, an attempt to answer the question 'At what stage is the implementation of PPP projects as a form of delivering public services' was made.

\section{Introduction}

Although the place and the role of the private sector in delivering pubic services is not a new issue in contemporary economics, it is still difficult to answer the question unambiguously: 'how much should the state be engaged in the economy?' The answer to this question is difficult because of the specific nature of public services. They are defined as public administration actions related to the provision of a particular good to which 
all citizens have access. Administrative, social and communal services are distinguished amongst public services (Szczudlińska-Kanoś, 2012).

In the 1980s, as a result of the financial crisis, the attention was paid to the private sector as a source of financing public investments. What is more, the effectiveness of the use of financial resources in the public sector was critically assessed, and the quality and level of services offered did not fully satisfy the purchasers. These considerations have caused that the objective scope of the public sector started to be limited. Currently, it is believed that there are no goods and services that can be provided only by the public or private sector (Stiglitz, 2004). Governments entrust the implementation of public services or even investments to private entities. They make use of a form of public-private partnership PPP, which aims to create the components of infrastructure enabling the delivery of public services.

Problematic aspects of PPP have been the subject of scientific research for years and are well known theoretically. The European Commission also supports PPP through directives, communications and other elaborations. It could seem that the implementation has a wide range and high intensity. However, the economic practice has shown that achieving benefits without negative effects is more difficult than literature has indicated. Problems in implementing the partnership have occurred in many EU countries. It was an impulse to undertake research on factors of PPP success.

In Poland in 1997 the first concession contract was signed with a private investor for the construction and exploitation of the A2 motorway. The period of 20 years of experience in PPP implementation has led to the analysis and evaluation, The question is: at what stage is the process of implementing PPP as a form of delivering public services? The article is an attempt to answer this question.

As a fundamental research method, the cause and effect analysis is used to explain the economic phenomena and the conditions that are taking place in the implementation of the partnership. Indirect empirical research, particularly literature, and the monographic method have shown the interest in problematic aspects of PPP, and have helped identify success factors. Further empirical studies, which were based on statistical data, have shown the level of PPP development in Poland in comparison to the European market. Then, using the inductive and diagnostic method, the PPP factors in terms of the degree of their fulfillment were analyzed. This allowed us to define the stage of implementing the partnership in Poland.

\section{PPP - litepatupe review}

The problem of public and private sector co-operation in delivering public services is not a new issue in western countries. One of the first scientists dealing with this issue was the professor of the Columbia University - Savas (1982). Research on not only financing but also operation and management of public infrastructure by the private sector was conducted in the 1990s by Osborne and Gaebler (1993). Out of the European countries, the Great Britain implemented various forms of public and private sector co-operation at the earliest and with the largest scale. At the initiative of the government agency - The Private Finance Initiative, a number of theoretical and research papers have been created on the role of private sector in public services and infrastructure (Jackson, Price, 1994; Gayle, Goodrich, 1990).

The concept of public-private partnership itself in the subject literature is defined as a type of agreement between a public partner and a private one, who work together on the project while at the same time they have their own goals and interests. They cooperate on the basis of a clearly defined division of risk and responsibilities 
(Flyvbjerg, Bruzelius, Rothengatter, 2003). The result of this cooperation should be a lower cost of the enterprise and a higher quality of services than if they were funded traditionally - from public funds. The form of involvement of private entities in PPP projects depends on its specificity and individual needs of project participants. Detailed classification was presented by among others Mu, de Jong, ten Heuvelhof (Mu, de Jong, ten Heuvelhof, 2010).

In the context of the European structures public-private partnership is an area of interest for the European Commission, especially in the context of the construction of the trans-European network TEN. The Commission supports PPP, because it provides the opportunity to raise private capital, and helps fill the gap between investment needs and available funds of the countries. European legislation documents and other documents such as The Lisbon Strategy of 2000, The White Book of 2011 or an Investment plan for Europe called 'Jucker Plan' created in 2015, indicate the commitment of the Commission. The Commission commissioned to develop guides which were to help with practical implementation of PPP - Guidelines for Successful PPP, A Guide to Guidance.

In Poland PPP studies are relatively new and have been developing since 2000. Their scope includes the use of PPP in widely understood activity of public utility (Moszoro, 2011) as well as in selected areas (Kopańska, Bartczak, Siwińska-Gorzelak, 2008). The analysis of the conditions for PPP development in Europe in terms of institutional environment was taken by Brzozowska (2010).

The subject literature shows also that the success of the partnership requires creating appropriate economic, legal, institutional and social conditions (Galilea, Medda, 2010). The conditions favouring the implementation of PPP are defined as critical success factors CSFs. Their identification was the subject of wide research conducted by Harcattle, Edwards and Akintoye (2005), which resulted in distinguishing five main groups of factors, i.e.: the effective purchasing process, the possibility of project implementation, the government guarantee, favourable economic conditions and available financial market.

For further analysis factors were classified into 4 groups: economic and financial, political and legal, technical, and social. These factors have a varied effect on the PPP success. The study of Chou, Tserng, Lin and Yeh (2012) shows, that at the macro level the following things have the strongest influence: stable macroeconomic conditions, economic and political support of the government, availability of financing, legal system, competent advisory public agencies, social support, transparent ordering process, competition in the ordering process.

\section{Analysis of the PPP implementation in Poland}

Examining the level of PPP development in Poland, this issue is worth considering in comparison to the market in Europe. Figure 1 shows the development of the European PPP market in 2003-2016, based on research conducted by the European PPP Expertise Centre EPEC. Data includes large investment projects - up to 2010 they were projects worth over 5 million euro, and since 2011 over 10 million euro.

The PPP market was developing dynamically until 2008. This trend was hindered by the global economic and financial crisis, and the recent years 2014-2016 have brought a further decline of the value of the projects.

By the end of the twentieth century the PPP market was developing mainly in the Great Britain. This tendency continues, and the Great Britain remains an unquestioned leader of the European PPP market (Figure 2).

Compared to other EU countries, the market value of projects in Poland is very small - in 2012-2016 it was only $0.3 \%$ of the total value. 


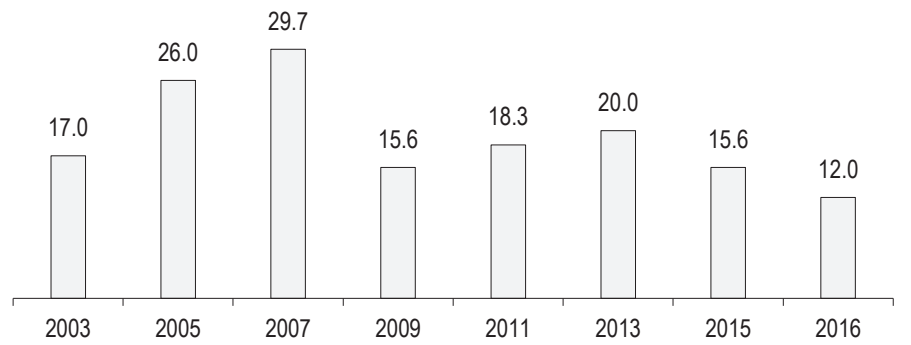

Figure 1. European PPP market 2003-2016, in EUR bn (EPEC, 2017)

Source: own elaboration, based on Review of the European PPP Market in 2012, 2014, 2016 (www.eib.org/epec).

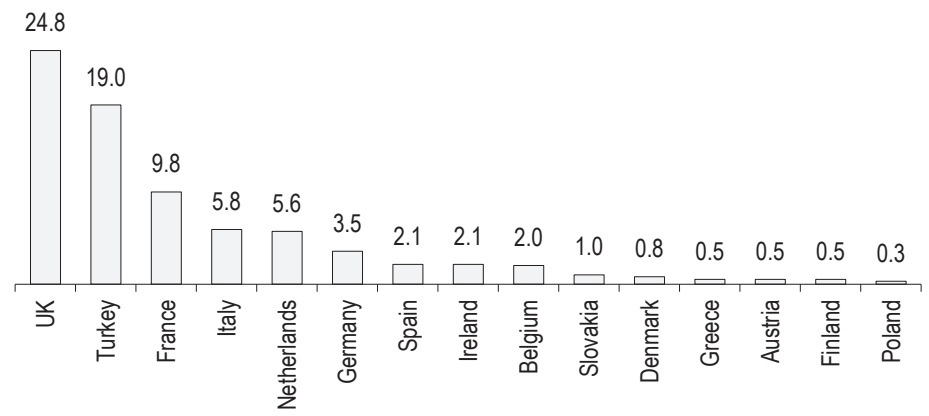

Figule 2. The European PPP market by country over the period 2012-2016, in EUR bn (EPEC, 2017) Source: own elaboration, based on Review of the European PPP Market in 2012, 2014, 2016 (www.eib.org/epec).

Analysis of this market (Korbus, 2016), covering the years 2009-2016 allowed to identify the following characteristics:

- the projects are mainly initiated by local governments,

- the contribution of the public side to the enterprise was to provide a property on which a private partner was to build the infrastructure based on the rule 'land for infrastructure',

- most of the agreements were signed by the local governments, which are large economically active urban agglomerations,

- 470 PPP auctions were initiated and 112 contracts were signed, so only $25 \%$ of the auctions were successful,

- the largest number of agreements was for small projects worth up to 1 million euro - $44 \%$ of the total number, however, the agreements worth over 60 million euro represented only $6 \%$,

- the contracts are implemented in the following sectors: sport and tourism - $23 \%$, transport infrastructure $13 \%$, water and sewage $-6 \%$, healthcare $-6 \%$.

The Polish market can be described as 'under construction'.

The success of PPP implementation requires fulfilling critical success factors, especially at the macro level. They form a fundamental framework for the functioning of the partnership, without them the PPP formula will not exist, not to mention a successful implementation. A detailed analysis of these factors was presented by the 
author in the previous publications (Zagożdżon, 2016). Here, however, only relevant research conclusions will be presented, formulated with reference to the most important factors: legal system, the support of the government, and particularly the activities of the public advisory agencies, availability of financing.

Stable law and certainty of its interpretation is a key and necessary condition for the PPP implementation. In Poland, the first law which enabled the private sector to implement road investments was set up in 1994. Practical implementation showed problems, and consequently the law was changed and amended - in 2000 and 2005. The first law on PPP, which gave the possibility for a wide application of this concept by the authorities of all levels, was passed in 2005. This law has formalized the way of carrying out the project analysis at the pre-implementation stage. It was a difficulty which caused that no investments were realized during its validity. After three years, in 2008, a new, more flexible law was passed which initiated the real process of implementation of public tasks in the PPP formula. At present there are relatively few obstacles of a purely legal nature. The regulations are so flexible that even political changes do not exclude interest in PPP (Wachowska, 2016).

However, the problem which has not been resolved unambiguously yet is the impact of liabilities of PPP contracts on the level of the public debt. The possibility to finance investments without charging the limits of liabilities is one of the fundamental prerequisites of public involvement in PPP contracts. Another issue is the lack of clear guidelines regarding the way and consequences of attributing particular risks to individual partners. The correct allocation of risks is a basic action which determines the impact on the debt level of local governments and the profitability of projects.

The position of banks is also important for the implementation of PPP projects. External financial support is relevant at such an early stage as technical preparation of the project, analysis and the selection process of the private partner. In practice funding in mainly provided to the projects which meet one of the two criteria: limited financial involvement of a public partner or a small scale of a project that allows a private partner to make a financial contribution themselves, and repetitiveness of the project. This approach is quite restrictive and a large proportion of projects are not financed. At the same time, banks are willing to provide communities with investment or current loans which have easy procedures and are safe.

The government support and the work of public advisory agencies is a very important factor for PPP success. On the initiative of the Ministry Of Development, the PPP platform was established in 2011, which aims to help to prepare and implement projects. However, the conducted research shows that this support is not enough. There is a lack of extensive training program for public administration staff, private sector and bank staff. Consequently, there is a lack of experienced, well-prepared employees. Another problem is a lack of pilot projects, poor use of positive experiences, a lack of model documents and standards.

The long-standing lack of public advisory institutions causes that the practice of employing an external advisor has not been disseminated - $47 \%$ of the entities did not use their help. In the total number of PPP auctions only $25 \%$ end up with signing an agreement, in many cases auctions are repeated because there is a lack of interest of private investors (Korbus, 2016). Not flexible enough approach to PPP contracts does not help either. One may think that the public side perceives PPP as a characteristic experiment, and while starting auctions they want to check if PPP can succeed in implementing the project.

A currently implemented project 'Development of public-private partnership in Poland' is an element of PPP support from the government. Its main objective is to improve the qualifications of public administration employees, and the actions include free trainings, workshops, visits and study missions, debates. 


\section{Conclusions}

A review of the theoretical assumptions and determinants of PPP implementation as a form of public service delivery has allowed to identify the most important determinants: the legal system, government support, in particular the activities of public advisory agencies, the availability of funding. Analysing and evaluating the process of implementing PPP in Poland, one can conclude that the legal regulations are quite well adapted to the specificity of the partnership, however, insufficient support of the government and public institutions is still a problem. The government does not initiate large projects whose success would be promotion and encouragement for using PPP. Involvement of both public advisory institutions and banks in projects is not enough, there is a lack of wide range of trainings and workshops. Inadequate knowledge of PPP leads to the situation that public entities, private investors, banks are cautious and sustainable.

The PPP market analysis shows that the barriers are gradually eliminated, but the pace of these changes is slow. The further development of the partnership and its intensification depends on the activeness of the government and its institutions in spreading knowledge and good PPP practices.

Continuous monitoring and updating PPP implementation as a form of public service delivery in Poland may be the direction for further research. It is worth carrying out an in-depth CSF analysis, using statistical methods and econometric models. The purpose of these studies may be to determine the degree to which these factors are met in economic practice.

\section{Referencess}

A Guide to Guidance. Sourcebook for PPPs (2010). Brussels: EPEC, EIB.

Brzozowska, K. (2010). Public-Private Partnership in Europe. Goals, conditions, effects. Warsaw: CeDeWu.

Cenkier, A. (2011). Public-Private Partnership as a method of performing public tasks. Warsaw: SGH publications.

Chou, J.-S., Tserng, H.P., Lin, Ch., Yeh, Ch.-P. (2012). Critical factors and risk allocation for PPP policy: Comparison between HSR and general infrastructure projects. Transport Policy, 22, 36-48.

Flyvbjerg, B., Bruzelius, N., Rothengatter, W. (2003). Megaprojects and Risk: An Anatomy of Ambition. UK: Cambridge University Press.

Galilea, P., Medda, F. (2010). Does the political and economic context influence the success of a transport project? An analysis of transport public-private partnerships. Research in Transportation Economics, 30, 102-109.

Gayle, D.J., Goodrich, V. (1990). Privatisation and Deregulation in Global Perspective. London Printer.

Guidelines for Successful PPP (2003). European Commission, Directorate-General Regional Policy. Brussels.

Hardcastle, C., Edwards, P.J., Akintoye, A., Li, B. (2005). Critical success factors for PPP/PFI projects in the UK construction industry: a factory analysis approach. in Proceedings: Public private partnerships e Opportunities and challenges. Hong Kong Convention and Exhibition Centre, 75-83.

Jackson, P., Price, C. (1994). Privatization and Regulation: A Review of the Issues. London: Longman Group Ltd., 1-34.

Kopańska, A., Bartczak, A., Siwińska-Gorzelak, J. (2008). Public-Private Partnership. Private entities in the implementation of public tasks of water and sewerage sector. Warsaw: CeDeWu.

Korbus, B. (ed.) (2016). Analysis of the PPP market for the period from 2009 to 315t. Warsaw. PPP Institute. Retrieved from www.ppp. gov.pl (30.05.2017).

Moszoro, M. (2010). Public-Private Partnership in the public utility sphere. Warsaw: Oficyna Wolters Kluwer.

Mu, R., de Jong, M., ten Heuvelhof, E. (2010). A Typology of Strategic Behaviour in PPPs for Expressways: Lessons from China and Implications for Europe. EJTIR, 1 (10).

Osborne, D., Gaebler, T. (1993). Reinventing government - how the entrepreneurial spirit is transforming the public sector. New York: Plume.

Review of the European PPP Market in 2016 (2017). EIB, EPEC. Retrieverd from: www.eib.org/epec (26.05.2017). 
Savas, E.S. (1982). Privatizing the Public Sector: How to Shrink Government. New York: Chatham House.

Stiglitz, J.E. (2004). The economy of public sector. Warszawa: Wydawnictwo Naukowe PWN.

Szczudlińska-Kanoś, A. (2012). Political determinants of delivering social services. Scientific Letters of the University of Szczecin. Economic Problems of Services, 95, 55-56.

Wachowska, A. (ed.) (2016). PPP regulations in selected EU countries and polish law - possibilities of change. Retrieved from: www. traple.pl (28.05.2017).

Zagożdżon, B. (2016). Public-Private Partnership and the development of transport infrastructure in Poland - the analysis of critical success factors. Springer Proceedings in Business and Economics, 125-138.

Cite this anticle aS: Zagożdżon, B. (2018). Public-private partnership PPP as a form of delivering public services. European Journal of Service Management, 2 (26), 337-343. DOI: 10.18276/ejsm.2018.26-42. 